\title{
Efektivitas Ekstrak Ethanol Daun Mimba terhadap Rhipichepalus sanguineus secara In Vitro
}

\section{(THE EFFECTIVENESS OF NEEM LEAF ETHANOL EXTRACT ON THE IN VITRO OF RHIPICHEPALUS SANGUINEUS)}

\section{Made Merdana ${ }^{1 *}$, Ida Ayu Pasti Hapsari ${ }^{2}$, Fuady Muslih ${ }^{3}$}

\author{
${ }^{1}$ Laboratorium Fisiologi, Farmasi dan Farmakologi Veteriner, ${ }^{2}$ Laboratorium Parasitologi \\ Veteriner, ${ }^{3}$ Pendidikan Profesi Dokter Hewan, Fakultas Kedokteran Hewan, Universitas \\ Udayana. Jl. P.B. Sudirman, Denpasar, Bali. \\ *Email: imade_merdana@unud.ac.id
}

\begin{abstract}
ABSTRAK
Tanaman mimba sangat potensial untuk dikembangkan sebagai obat antiektoparasit pada hewan kesayangan. Tujuan dari penelitian ini untuk mengetahui efektivitas ekstrak ethanol daun mimba (Azadirachta indica, A. Juss) terhadap caplak Rhipicephalus sanguineus secara in vitro. Menggunakan rancangan acak lengkap, sebanyak 250 ekor caplak secara acak dibagi menjadi 5 group dengan lima ulangan. P0 diberikan placebo sebagai kontrol negatif. P1 diberikan deltametrin 0,5\% EC sebagai kontrol possitif. P2, P3 dan P4 secara berurutan diberikan ekstrak daun mimba 2,5\%, $5 \%$ dan 10\%. Setiap ulangan berisi 10 ekor caplak yang ditaruh didalam petridish beralaskan kapas yang telah disemprot dengan larutan masing-masing, kemudian caplak diberikan perlakuan lagi dengan penyemprotan secara halus dan merata. Hasil penelitian menunjukkan bahwa ekstrak ethanol daun mimba berpengaruh sangat nyata $(\mathrm{P}<0,01)$ terhadap kematian caplak $R$. sanguineus secara in vitro. dimana terjadi peningkatan kematian caplak seiring meningkatnya konsentrasi. Pada penelitian ini dapat disimpulkan bahwa ekstrak ethanol daun mimba 5\% yang paling efektif membunuh caplak $R$. sanguineus dengan mortalitas $100 \%$.
\end{abstract}

Kata kunci: efektivitas; ekstrak ethanol daun mimba; Rhipicephalus sanguineus

\section{ABSTRACT}

The Neem leaves were very potential to developed as an anti-ectoparasite drug in pets. The purpose of this research was to determine the effectiveness of ethanol extract of Neem leaves (Azadirachta indica, A. Juss) against Rhipicephalus sanguineus dog by in vitro. Using a completely randomized design, 250 ticks were randomly divided into 5 groups with five repetitions. A gentle spray treatment of neem leaves extract, sequentially; $\mathrm{P} 0$ as negative control with Aquadest, $\mathrm{P} 1$ as positive control with $0.5 \%$ deltamethrin, $\mathrm{P} 2$ with $2.5 \%$ Neem leaves extract, P3 with 5\% Neem leaves extract, P4 with $10 \%$ Neem leaves extract, Each group consists of 12 ticks that placed in petri dish with a cotton pad that has been sprayed with each solvent, then treated again by spraying it gently and equal. The results of the research showed that the ethanol extract of neem leaves proved to be very significant $(\mathrm{P}<0.01)$ against the mortality of $R$. sanguineus by in vitro. This research, solvent with $10 \%$ of neem leaves extract was most effective to exterminate $R$. sanguineus ticks with $100 \%$ mortality.

Keywords: effectiveness; neem leaves extract; Rhipicephalus sanguineus

\section{PENDAHULUAN}

Ektoparasit yang sering ditemukan menyerang anjing adalah caplak Ixodidae salah satunya Rhipicephalus sanguineus. Infestasi caplak menyebabkan performa anjing menjadi tidak menarik untuk dilihat, terjadi kerontokan bulu dan juga infeksi pada kulit. Infestasi caplak menyerang permukaan kulit induk semang dengan menghisap darah dari pembuluh darah perifer (Levine, 1994). Caplak juga sebagai vektor penularan berbagai macam penyakit yang disebut tick borne diseases (Rani et al., 2011), seperti boutenneuse fever, babesiosis, ehrlikiosis dan demam Q (Hadi dan Sovianan, 2015). Berbagai metode penanggulangan menggunakan pestisida 
sintetis telah dilakukan dengan cara dusting, spraying, bathing-dipping dan juga injection. Implikasinya terjadi ketergantungan akan pestisida sintetis dengan dosis yang terus meningkat. Penggunaan pestisida yang berulang dapat berdampak negatif bagi anjing dan mahluk bukan sasaran serta tidak ramah lingkungan (Stenersen, 2004).

Penelaahan senyawa alami sebagai kandidat antiparasit semakin berkembang pesat. Telah dilaporkan kandungan fitokima pada akar tuba efektif membunuh caplak pada anjing (Hutasoit et al., 2015) dan pinjal pada kucing (Setiawan et al, 2014). Senyawa aktif sejenis juga ditemukan pada tanaman mimba (Azadirhacta. indica, A. Juss), sehingga sangat potensial dikembangkan sebagai insektisida alami. Senyawa aktif yang terkandung dalam tanaman mimba meliputi alkaloid, steroid, flavonoid, triterpenoid, polyfenol, tanin dan kuinon (Javandira et al., 2016: Whiteford et al., 2017). Triterpenoid pada tanaman mimba disebut azadirachtin, yang telah terbukti mampu mengendalikan berbagai serangga hama (insekta) dalam bidang pertanian (Samsudin, 2011). Azadirachtin menyebabkab serangga mengalami neurotoxic sehingga menyebabkan paralisis dan mati (Roma et al., 2013).

Penelitian lain menyebutkan bahwa ekstrak etanol daun mimba konsentrasi $2 \%$ efektif mengendalikan populasi serangga pengganggu A. Gossypii pada tanaman nilam (Mardiningsih et al., 2010), bersifat larvasida terhadap nyamuk aedes aegypti dengan LC50 1.583\% (Susanthi, 2015), mengendalikan hama Plutella xylostella $L$ (Bukhari, 2011) serta menurunkan infestasi serangan caplak anjing (Wirawan et al., 2010). Melihat kemampuan senyawa aktif pada tanaman mimba tersebut diatas, maka sangat potensial untuk dikembangkan sebagai antiektoparasit pada hewan kesayangan. Untuk itu pada penelitian ini akan dilakukan uji efektivitas ekstrak ethanol daun mimba terhadap caplak $R$. sanguineus secara in vitro.

\section{METODE PENELITIAN}

\section{Ekstraksi Daun Mimba}

Daun mimba yang digunakan berasal dari Kecamatan Kubutambahan, Buleleng, Bali, Indonesia. Daun segar dibersihkan dan dipotong kecil-kecil, kemudian dikering-anginkan dengan meletakkan di tempat terbuka dengan sirkulasi udara yang baik dan terhindar sinar matahari langsung. Daun yang kering kemudian diblender sampai berbentuk serbuk halus, kemudian dimaserasi menggunakan etanol $90 \%$ dengan perbandingan 1:3 (w/v). Pada penelitian ini sebanyak 1 Kilogram serbuk daun mimba direndam dengan 3 liter ethanol $90 \%$. Campuran diaduk sampai merata dan didiamkan selama 3 hari. Selanjutnya dilakukan penyaringan untuk diambil filtratnya, dan kemudian diuapkan menggunakan evaporator sampai diperoleh ekstrak semisolid yang pekat (Zhang et al., 2018).

\section{Pembuatan Larutan Ekstrak Ethanol Daun Mimba}

Pembuatan larutan insektisida alami dari ekstrak ethanol daun mimba dilakukan dengan cara kalibrasi. Larutan konsentrasi $2,5 \%(\mathrm{w} / \mathrm{v})$ dibuat dengan cara menimbang ekstrak daun mimba sebanyak 2,5 g lalu dimasukkan kedalam labu ukur dan ditambahkan pelarut tween $2 \%$ sampai volumenya menjadi $100 \mathrm{ml}$. Cara yang sama dilakukan dalam pembuatan larutan ekstrak ethanol daun mimba 5\% dan $10 \%$. Masing-masing larutan dimasukkan kedalam sprayer yang telah ditandai untuk penelitian. Proses pembuatan konsentrasi larutan dalam penelitian ini merujuk pada metode kalibrasi seperti yang digunakan oleh Setiawan et al. (2014) dan Hutasoit et al. (2015).

\section{Pelaksanaan Penelitian}

Tahap persiapan petridish diberi alas kapas secara merata dan disemprot dengan larutan yang telah disiapkan. Selanjutnya caplak $R$. sanguineus sebanyak 250 ekor secara acak dibagi menjadi lima group dengan lima ulangan, sehingga masingmasing petridish berisi 10 ekor caplak. Perlakuan dengan cara penyemprotan 
(spraying) secara halus masing-masing; $\mathrm{P} 0$ sebagi kontrol negatif disemprot dengan aquadest, P1 sebagi kontrol positif disemprot dengan deltametrin $0,5 \% \mathrm{EC}$, dan penyemprotan ekstrak ethanol daun mimba pada P2, P3 dan P4 dengan konsentrasi $2,5 \%, 5 \%$ dan $10 \%$.

Pengamatan terhadap caplak mati dilakukan pada waktu yang telah ditentukan. Pengamatan pertama pada jam ke-0 yaitu dimulai setelah penyemprotan sampai satu jam pertama, dan dilanjutkan pengamatan pada akhir jam ke-4, ke-8 dan ke-12 setelah perlakuan. Penentuan caplak mati dengan cara membalik tubuh caplak dari ventral ke dorsal secara perlahan. Caplak dinyatakan mati apabila tidak mampu membalikkan tubuh ke posisi seperti semula dan atau tidak ada pergerakan sama sekali. Jumlah caplak yang mati akan ditetapkan sebagai mortalitas atau angka kematian akibat perlakuan berbagai konsentrasi ekstrak ethanol daun mimba.

\section{Analisis Statistik}

Data jumlah kematian caplak akan ditabulasi dan dinyatakan dengan persentase kematian, dan dianalisis menggunakan uji friedman dan dilanjutkan uji wilcoxon (Steel dan Torrie, 1993).

\section{HASIL DAN PEMBAHASAN}

Hasil uji efektivitas ekstrak ethanol daun mimba terhadap caplak $R$. sanguineus secara in vitro, diperoleh mortalitas caplak setelah 12 jam pengamatan secara berurutan pada konsentrasi $0 \% \quad(\mathrm{P} 0)$, deltamethrin $0,5 \%$ EC (P1), 2,5\%(P2), $5 \%$ (P3) dan 10\% (P4), yaitu 0\%, 100\%, 68\%, $100 \%$ dan $100 \%$. Data pengamatan perkembangan mortalitas caplak secara rinci disajikan pada Tabel 1.

Tabel 1. Mortalitas R. sanguineus setelah perlakuan berbagai konsentrasi ekstrak ethanol daun mimba

\begin{tabular}{|c|c|c|c|c|}
\hline Group & $\begin{array}{c}\text { Waktu Pengamatan } \\
\text { (jam ke-) }\end{array}$ & N Caplak awal (ekor) & N Caplak mati (ekor) & $\begin{array}{c}\text { Kematian Caplak } \\
(\%)\end{array}$ \\
\hline & 0 & 50 & 0 & 0 \\
\hline $\mathrm{P} 0$ & 4 & & 0 & 0 \\
\hline \multirow[t]{3}{*}{ (Placebo) } & 8 & & 0 & 0 \\
\hline & 12 & & 0 & 0 \\
\hline & 0 & 50 & 50 & 100 \\
\hline P1 & 4 & & 50 & 100 \\
\hline \multirow[t]{3}{*}{ (Deltametrin $0,5 \% \mathrm{EC}$ ) } & 8 & & 50 & 100 \\
\hline & 12 & & 50 & 100 \\
\hline & 0 & 50 & 0 & 0 \\
\hline $\mathrm{P} 2$ & 4 & & 5 & 10 \\
\hline \multirow[t]{3}{*}{ (Ekstrak Mimba 2,5\%) } & 8 & & 24 & 48 \\
\hline & 12 & & 34 & 68 \\
\hline & 0 & 50 & 0 & 0 \\
\hline P3 & 4 & & 35 & 70 \\
\hline \multirow[t]{3}{*}{ (Ekstrak Mimba 5\%) } & 8 & & 41 & 82 \\
\hline & 12 & & 50 & 100 \\
\hline & 0 & 50 & 0 & 0 \\
\hline P4 & 4 & & 42 & 84 \\
\hline \multirow[t]{2}{*}{ (Ekstrak Mimba 10\%) } & 8 & & 48 & 96 \\
\hline & 12 & & 50 & 100 \\
\hline
\end{tabular}

Analisis statistika menggunakan Uji Friedman menunjukkan bahwa ekstrak ethanol daun mimba berpengaruh sangat nyata $(\mathrm{P}<0,01)$ terhadap mortalitas caplak $R$. sanguineus secara in vitro. Untuk mengetahui perbedaan penngaruh 
konsentrasi ekstrak ethanol daun mimba terhadap kematian caplak dilanjutkan dengan Uji Wilcoxon. Hasil analisis menunjukkan konsentrasi berpengaruh nyata terhadap mortalitas caplak $R$. sanguineus,. Mortalitas caplak meningkat seiring meningkatnya konsentrasi ekstrak. Hasil terbaik ditunjukkan pada perlakuan dengan konsentrasi ekstrak ethanol daun mimba 5\%, yang efektif membunuh $R$. sanguineus sampai $100 \%$.

Metabolit aktif berupa triterpenoid yang terkandung pada tumbuhan mimba disebut dengan Azadirhactin. Zat ini telah lama dimanfaatkan sebagai bahan aktif insektisida alami dan terbukti dapat mengendalikan lebih dari 300 spesies serangga hama. Azadirachtin memiliki molekul kimia C35H44O16, strukturnya identik dengan hormone "ecdysone" pada serangga yang berperan mengatur proses metamorphosis (Samsudin, 2011). Azadirachtin diduga meniru dan mengambil tahapan kerja hormon tersebut, dan menimbulkan efek sebagai antagonis hormon pertumbuhan, menimbulkan efek antifeedant, mengganggu perkembangan telur dan larva, terjadinya gangguan reproduksi dan kemandulan, ganguuan pembentukan chitin, gangguan sistem saraf dan sebagai repellan (Matsumura, 1985; Stenersen, 2004). Pada penelitian ini, diduga aktivitas yang sama dari senyawa aktif diatas menyebabkan kematian caplak $R$. sanguineus.

Mekanisme kerja dari azadirachtin secara molekuler belum dipahami secara menyeluruh dan efek yang muncul bisa berbeda pada masing-masing spesies. Caplak memiliki sistem peredaran darah terbuka, dan sistem saraf tunggal yang sederhana (Levine, 1994). Senyawasenyawa aktif yang terdapat pada ekstrak daun mimba juga diyakini merusak lemak dan kutikula pada lapisan kitin tubuh serangga, sehingga memudahkan penetrasi azadirachtin masuk kedalam tubuh serangga, dan berdampak pada sistem pernafasan dan sistem saraf (Matsumura, 1985). Diduga pada perlakuan ekstrak daun mimba denga cara spraying, memungkinkan azadirachtin masuk kedalam tubuh serangga melalui kutikula, spirakel mapun organ sensorik lainnya (Stenersen, 2004). Pada caplak anjing, selain melalui kutikula, azadirachtin juga masuk melalui mulut mencapai saluran pencernaan, sistem trakeal pernafasan dan masuk mencapai peredaran darah dan sistem saraf, dan diduga berperan pula sebagai racun saraf dan racun kontak (Roma et al., 2013).

Penetrasi azadirachtin kedalam tubuh caplak anjing, akan beraksi dengan cara menghambat transfer elektron antara $\mathrm{FeS}$ dan coenzim Q pada mitokondria sel. Hal ini berhubungan dengan kardiotoksisitas, depresi respirasi, dan blok pada konduksi saraf. Azadirachtin diduga menyebabkan gangguan pada siklus oksidasi repirasi mitokondria sel dengan menyekat perpindahan elektron dari kompleks protein besi sulfur (FeS) ke Ubiquinon (Q) sehingga jumlah ATP sebagai sumber respirasi berkurang. Kekuranga energi berakibat terjadi gangguan proses-proses penting dalam tubuh organisme seperti proses respirasi, kontraksi jantung, saraf respirasi yang mengakibatkan caplak mengalami kematian (Katzung, 2004). Metabolit aktif ini mampu beredar keseluruh tubuh caplak bersama peredaran darah, hal ini sangat memungkinkan mencapai sistem saraf dan diduga secara selektif menyerang ganglion pusat saraf. Saraf pusat pada pada caplak terdiri dari sepasang rantai saraf yang terdapat di sepanjang tubuh bagian ventral, pada tiap segmen terjadi suatu pengumpulan saraf tubuh yang disebut ganglion (Roma et al., 2013). Kelompok ganglion yang terdapat di dekat mulut dianggap sebagai otak yang menghasilkan hormon-hormon, satu diantaranya hormon ekdison yang bertanggung jawab terhadap proses perkembangan tubuh. Gangguan pada ganglion-ganglion saraf tersebut, menyebabkan kerja hormon ekdison terganggu dan akan menghambat proses metamorfose dan perkembangan caplak. 
Kerusakan ganglion menyebabkan sel-sel saraf mengalami kelumpuhan sehingga terjadi paralisis anggota gerak yang berakhir dengan kematian (Matsumura, 1985).

Mekanisme yang sama diduga ditunjukkan oleh flavonoid (rotenone) yang terkandung dalam ekstrak akar tuba, yang dalam hitungan menit menyebabkan kematian pinjal kucing (Setiawan et al., 2014) dan kematian caplak anjing (Hutasoit et al., 2015). Pada penelitian ini ekstrak ethaol daun mimba pada konsentrasi $5 \%$ dan $10 \%$ efektif membunuh caplak sampai $100 \%$ secara in vitro. Hasil ini sejalan dengan yang dilaporkan oleh Wirawan et al (2010), bahwa kandungan bahan aktif daun mimba mampu menurunkan infestasi caplak secara in vivo.

\section{SIMPULAN}

Ekstrak ethanol daun mimba efektif membunuh caplak Rhipicephalus sanguineus secara in vitro. Hasil terbaik terbaik ditunjukkan pada konsentrasi 5\% dengan mortalitas caplak $100 \%$.

\section{UCAPAN TERIMAKASIH}

Penulis mengucapkan terimakasih banyak kepada Dekan Fakultas Kedokteran Hewan, Ketua Lembaga Penelitian dan Pengabdian Masyarakat dan Rektor Universitas Udayana atas pendaanaan penelitian melalui PNBP Universitas Udayana dengan kontrak No. 1108/UN14.2.9/LT/2018.

\section{DAFTAR PUSTAKA}

Bukhari. 2011. Efektifitas ekstra daun mimba terhadap pengendalian hama Plutella xylostella L. pada tanaman kedele. J. Sains Riset. 1(1): 11.

Hadi UK, Soviana S. 2015. Prevalence of ticks and tick-borne diseases in Indonesian dogs. J. Vet. Sci. Technol. 07(3): 15-20.

Hutasoit IH, Siswanto, Merdana IM. 2015. Uji efektivitas ekstrak akar tuba (Derris elliptica) terhadap caplak anjing secara in vitro. Indonesia Mediscus Veterinus. 4(2): 122-128.

Javandira C, Widnyana IK, Suryadarmawan IGA. 2016. Kajian fitokimia dan potensi ekstrak daun tanaman mimba (Azadirachta indica, A. Juss) sebagai pestisida nabati. Prosiding Seminar Nasional. Unmas Denpasar. Pp: 402-406.

Katzung BG. 2004. Basic and Clinical Pharmacology. $9^{\text {th }}$. The McGraw-Hill Companies. United State.

Levine ND. 1994. Buku Ajar Parasitologi Veteriner. Yogyakarta. Terjemahan: G. Ashandi. Gadjah Mada University Press.

Mardiningsih TL, Sukmana C, Tarigan N, Surati S. 2010. Efektivitas insektisida nabati berbahan aktif azadirachtin dan saponin terhadap mortalitas dan itensitas serangan aphis gossypii glover. Buletin Littro. 21(2): 171-183.

Matsumura F. 1985. Tocxicology of Pesticides. Plenum Press. New York. Pp: 17-22.

Rani PAMA, Irwin PJ, Coleman GT, Gatne M, Traub RJ. 2011. A survey of canine tick-borne diseases in India. Parasites Vectors. 4: 141.

Roma GC, Mathias MIC, Oliveira PR, Furquim KCS, Bechara GH. 2013. Neurotoxic action of permethrin in Rhipicephalus sanguineus (Latreille, 1806) (Acari: Ixodidae) female ticks; Morphological and cytochemical evaluation of the central nervous system. Vet. Parasitol. 196(3): 482491.

Samsudin. 2011. Biosintesa dan cara kerja azadirachtin sebagai bahan aktif insektisida nabati. Prosiding Seminar Nasional Pestisida Nabati IV. Jakarta.

Setiawan PH, Siswanto, Merdana IM. 2014. Ekstrak akar tuba (Derris elliptica) efektif membunuh pinjal (Siphonaptera) kucing secara in vitro. Indonesia Mediscus Veterinus. 3(5): 323-429.

Steel RGD, Torrie JH. 1993. Principles and Procedurs of Statistics A. Biometrical 
Approach. $2^{\text {nd }}$ Ed. New York: McGrawHill. Kogakusha Ltd.

Stenersen J. 2004. Chemical Pesticides Mode of Action and Toxicology. CRC Press.

Wirawan IGKO, Jadi ML, Hadisutanto B. 2010. Efek ekstrak mimba sereh dan lengkuas terhadap infestasi caplak pada anjing. Patner. 1: 37-42.
Whiteford F, Fuhremann T, Rao KS, Klaunig JE. 2017. Pesticide Toxicology; Evaluating Safety and Risk. Purdue University. Cooperative Extension Service. West Lafayette.

Zhang QW, Lin LG, Ye WC. 2018. Techniques for extraction and isolation of natural products: A comprehensive review. Chin. Med. 13: 20. 